\title{
Waar lê die diepste punt(e) van verdeling tussen apartheids- teologie en die kritiese stemme daarteen binne die Ned Geref Kerk self?
}

\begin{abstract}
Where are the deepest points of divergence between apartheid theology and the critical voices against this theology within the Dutch Reformed Church?

This contribution focuses on the relationships between two theological schools within the Dutch Reformed Church (DRC), namely apartheid theology and the early critical voices against this theology from within the DRC itself, including Bennie Keet, Ben Marais en CF Beyers Naudé. The question that is addressed relates to the deepest points of divergence in this regard. The significance of this question is highlighted. Hermeneutical theory (in itself the product of such critical voices) is used as an instrument to identify a set of seven variables in this regard. The hermeneutical role of diverging "doctrinal keys" is emphasised.
\end{abstract}

\section{INLEIDING EN VRAAGSTELLING}

Hierdie bydrae fokus op die verhouding tussen twee teologiese strominge in die Nederduitse Gereformeerde Kerk, naamlik apartheidsteologie soos dit uiteindelik neerslag gevind het in Ras, volk en nasie en volkereverhoudinge in die lig van die Skrif (RVN) (1974) en vroeë verteenwoordigers van die sogenaamde "kritiese stem" vanuit die Ned Geref Kerk, waaronder persone soos Bennie Keet, Ben J Marais en CF Beyers Naudé.

Die vraag wat hier ondersoek word, is waar die diepste punte van verdeling tussen hierdie twee teologiese strominge lê? Daar was immers heelwat wat hierdie kritiese stem met die apartheidsteoloë in gemeen gehad het. Al die belangrikste verteenwoordigers van hierdie strominge het grootgeword binne dieselfde soort Afrikaner huishoudings waar hulle met gemeenskaplike waardes ten opsigte van godsdiens en kultuur gevorm is. Hulle is aan soortgelyke skole opgevoed en min of meer almal het later tersiêre onderrig aan die Universiteit van Stellenbosch ontvang. Hier is hulle blootgestel aan dieselfde kulturele en godsdienstige konteks, opvoeders en teologiese strominge. Hulle het dieselfde geskiedenis, taal, gereformeerde tradisie en kulturele erfenis gehad. Die vraag is daarom: Waarom het hulle uiteindelik so diepgaande van mekaar verskil ten opsigte van hulle teologiese posisies? Wat is ten diepste die onderliggende teologiese verskille tussen apartheidsteologie en die kritiese stem daarteen?

Die antwoord op hierdie vrae is nie sonder meer vanselfsprekend nie. (Coetzee 2010:364). Dit is moontlik om dié punte van verdeling te vind in terme van politieke blootstelling. Hier kan byvoorbeeld gewys word op die impak van die Sharpeville-slagting op die lewe van Naudé. Die rol van ekumeniese blootstelling in die lewe van Ben Marais kan insgelyks beklemtoon word.

1 Wat begin het met 'n verklaring by die Federale Raad van Ned Geref Kerke in 1935 oor die onaanvaarbaarheid van rassevermenging, sou uiteindelik uitloop op 'n teologie van apartheid. Dit het neerslag gevind in die rapport Ras, Volk en Nasie en volkereverhoudinge in die lig van die Skrif (RVN). Dié verslag is tydens die Algemene sinode van die Ned Geref Kerk in 1974 aanvaar. 
Beide hierdie gevalle laat egter nie reg geskied aan die teologiese punte van verdeling tussen hierdie twee strome nie. Watter hermeneutiese en teologiese uitgangspunte het die draers van die kritiese stem in staat gestel om apartheid en die teologiese verdediging daarvan te ontmasker? Wat het gemaak dat hulle - anders as die hoofstroom binne die Ned Geref Kerk die teologiese regverdiging van apartheid as 'n dwaling herken het?

Dit is nie nodig of moontlik om hierdie twee strominge in detail hier aan die orde te stel nie. Daar bestaan ' $n$ uitgebreide literatuur oor die ontstaan en ontwikkeling van apartheidsteologie wat hier gewoon veronderstel word. ${ }^{2}$ Daar is insgelyks voldoende literatuur oor die teologiese kritiek teen apartheidsteologie, veral vanuit 'n breër ekumeniese konteks. ${ }^{3}$ Oor die lewe en bydrae van figure soos Bennie Keet, Ben Marais en Beyers Naudé bestaan daar ook reeds vollengte studies. ${ }^{4}$ Die bydraes van ' $n$ volgende geslag van kritiese stemme teen apartheidsteologie vanuit die Ned Geref Kerk self - waaronder die name van David Bosch, Jaap Durand, Willie Jonker en andere genoem kan word - is ook reeds aan die orde gestel in die literatuur.

In hierdie bydrae word ' $n$ veralgemenende hipotese aangebied oor waar die diepste punte van verdeling in hierdie verband gevind kan word. In kort kom dit daarop neer dat daar by apartheidsteologie 'n bepaalde gebrek aan 'n historiese bewussyn en aan 'n hermeneutiese aanvoeling bespeur kan word. Daarteenoor het die draers van die kritiese stem hermeneutiese vrae steeds meer indringend aan die orde gestel. Dit het uiteindelik gelei tot uiteenlopende teologiese posisies oftewel "dogmatiese sleutels". In hierdie bydrae word gebruik gemaak van hermeneutiese analise ten einde hierdie punte van verdeling in meer detail bloot te lê. Die veronderstelling is dat die ontwikkeling van teologiese hermeneutiek as ' $n$ dissipline (in SuidAfrika veral sedert die 1960s) juis verstaan kan word vanuit die ongemak met die metodologiese veronderstellings van apartheidsteologie. Die produk van hermeneutiese nadenke kan dus met reg gebruik word om hierdie punte van verdeling te analiseer.

\section{'N HERMENEUTIESE VAKUUM}

In die standaardwerk oor die ontstaan van apartheidsteologie in die Ned Geref Kerk gebruik Johann Kinghorn die term "hermeneutiese vakuum" om die impak van die Du Plessis-stryd op teologiese ontwikkelinge na 1930 te beskryf (Kinghorn (1986: 55ev). Alhoewel Du Plessis die regsaak gewen het, het die stryd ' $n$ lang nawerking gehad waartydens die sogenaamde "Oupajane" (Coetzee (2010: 145) deur middel van organisasies soos die "Federasie van die Calvinistiese Studenteverenigings" en die "Kristelike-Nasionale Bond van Kalviniste in SuidAfrika" in die praktyk beheer oorgeneem het in die Ned Geref Kerk. Enige kritiese Skrifondersoek in die Ned Geref Kerk is geëtiketteer as modernisties, 'n demper is geplaas op enige interne kritiese denke en slegs teoloë wat sogenaamd "regdenkend" was, is aangestel as hoogleraars aan die teologiese kweekskole.

Hierteenoor het die Oupajane 'n terugkeer na die "ou paaie" bepleit oftewel na 'n verstarde vorm van gereformeerde ortodoksie. Hulle het hiervoor aansluiting gevind by die neo-Calvinisme

2 Vergelyk byvoorbeeld: Bax 1972; Boesak 1986; Bosch 1981, 1982, 1983, 1984; A J Botha 1984; De Gruchy 1979; De Klerk 1975; Deist 1986; Durand 1984; Du Toit 1983; Hexham 1981; Kinghorn 1986; Lombard 1974, 1981; Moodie 1975; Nolan 1988 en Villa-Vicencio 1988.

3 Die "kritiese stem" teen apartheid en apartheidsteologie word ook in verskeie ander werke bespreek. Sien byvoorbeeld: Bax 1979, AJ Botha 1984; CJ Botha 1979; De Gruchy 1986; Kinghorn 1986; Lategan 2004; Loubser 1987, Pauw 2008, Villa-Vicencio \& De Gruchy 1985, Walshe 1982, 1997. Soortgelyke kritiek kom ook vanuit die sogenaamde dogterkerke van die Ned Geref Kerk. Sien Adonis 1982; Boesak 1977 , 1983, 1984, 1987; Bosch 1982; Cloete 1984; Durand 1984; Mofokeng 1986.

4 Sien veral Engdahl 2006; Heaney 2004; Maritz 2003; Ryan 2005; Villa-Vicencio \& De Gruchy 1985. 
wat in Nederland ook geassosieer is met 'n terugkeer na gereformeerde oortuiginge. Ironies genoeg was die neo-Calvinisme van Kuyper en Bavinck weliswaar ' $\mathrm{n}$ poging om die skolastieke verstarring van die gereformeerde ortodoksie van die 17de en 18de eeue te deurbreek en is juis daarom as neo-Calvinisme gekritiseer.

Verskillende navorsers wys daarop dat apartheidsteologie nie net aansluiting gevind het by Kuyperiaanse neo-Calvinisme nie, maar ook by die Duitse volksromantiek, die sendingkunde van Warneck, Skotse vorme van piëtisme en ook by Princetonse fundamentalisme wat berus op die uitgangspunt van die onfeilbaarheid van die Skrif (Kinghorn (1986: 58ev). Die versmelting van hierdie tradisies in die Suid-Afrikaanse het tot 'n ongesofistikeerde vorm van teologiese hermeneutiek gelei waarvolgens gepoog is om ' $n$ vasstaande, ewig-geldende sisteem van waarhede en beginsels in die Skrif te identifiseer en dan op die Suid-Afrikaanse konteks van toepassing te maak. Hierdie werkswyse het enersyds daartoe gelei dat die historiese gesitueerdheid van Bybeltekste nie genoegsaam verreken is nie. Dit het andersyds daartoe gelei dat die dogmatiese sleutels, met behulp waarvan die tekste wel geïnterpreteer is, verabsoluteer is omdat dit teen enige vorm van kritiek gevrywaar is. Al te dikwels is ' $n$ bevraagtekening daarvan geassosieer met 'n bevraagtekening van die gesag of die "onfeilbaarheid" van die Skrif self - juis omdat die identifisering van ewig-geldende beginsels 'n poging was om die gesag van die Skrif en daarom 'n sekere kontinuïteit met die Bybel en die Christelike geloof te handhaaf.

Hierdie biblisistiese en fundamentalistiese vorm van eksegese kon in die praktyk egter nie verhoed dat hierdie waarhede en beginsels op grond van pragmatiese oorwegings (gestruktureer deur ervarings vanuit die Suid-Afrikaanse konteks) geïdentifiseer word nie. Hierdie oorwegings is ten beste verwoord in die Sendingbeleid van die Federale Sendingraad en die daaropvolgende volkskongresse van die 1930s en 1940s. Die teologiese regverdiging en Bybelse begronding van apartheid is uiteindelik gesistematiseer in 'n a-historiese kosmologie soos veral verwoord deur Stoker HG en uitgewerk in publikasies soos Koers in die Krisis en Die Gereformeerde Vaandel (vir 'n meer volledige bespreking, sien Coetzee 2010: 110ev).

In terme van hierdie kosmologie berus apartheid op die ordes wat God self in die skepping daargestel het. Hoewel hierdie kosmologie vryelik gebruik gemaak het van terminologie ontleen aan Kuyper, was die historiese bewussyn wat sterk by Kuyper funksioneer afwesig in die teologiese hermeneutiek van apartheidsteologie. Die wysbegeerte van die "wetsidee" in die neo-Calvinisme van Dooyeweerdt is herlei na ' $n$ "skeppingsidee" by Stoker: die ordening van die samelewing berus nie alleen op 'n orde wat in die geskiedenis ontstaan het nie, maar wat alreeds met die skepping self saamval (Stoker (1941). Alles, nie alleen die inrigting van die kerk nie maar ook van die burgerlike samelewing, moet hiervolgens in ooreenstemming met die skeppingsordes van God funksioneer. Mense se vryheid kan slegs verwesenlik word as hulle gehoorsaam is aan hierdie a-historiese beginsels - naamlik aan God se skeppingsordinansies. Hierdie ordinansies is selfs nie deur die sondeval ondermyn nie. Die mens is hiervolgens vanweë die sondeval nie in staat om hulle eie orde te skep nie en moet die skeppingsordinansies van God gehoorsaam. Dit mag deur geen ander orde vervang word nie, want enige ander orde is sogenaamd horisontaal of humanisties en dus liberaal en van meet af aan gedoem tot ondergang. Volgens Stoker (1941) moet die praktyk daarom volgens die beginsel (die teoretiese) verander word. Meer spesifiek is 'n verskeidenheid van rasse hiervolgens alreeds in die skepping deur God gewil, is deur God se "algemene genade" bevestig is en behoort daarom steeds gehandhaaf te word deur wet en orde en met mag en geweld, indien nodig. Die sosiale orde is daarom nie alleen geregverdig nie, maar ook afgedwing omdat God se a-historiese beginsels immers onaantasbaar is. Dit moet daarom deur die kerk en die burgerlike samelewing gehoorsaam word.

Die gebrek aan sodanige hermeneutiese bewussyn is waarskynlik die eerste keer gedurende die laat-1930's aangevoel en intuïtief verwoord deur BB Keet, toe hy verwys het na die 
gereformeerde ortodoksie as 'n "starre beweging" (Deist (1994: 279). In die briewe van AH Murray (1935) is hierdie gebrek aan 'n historiese bewussyn ook vroeg reeds raakgesien. Volgens hom skep die intellektualisering van die leer van Calvyn ernstige probleme vir die teologie van die Ned Geref Kerk. Uit sy analise blyk dit dat daar 'n gebrek was aan 'n kritiese Skrifstudie en hermeneutiek binne die Suid-Afrikaanse gereformeerde ortodoksie. Daarom was daar ' $n$ vrypas om hulle filosofiese stelsel in die Skrif in te lees en dit het aanleiding gegee tot die verkondiging van ' $n$ a-historiese filosofiese stelsel wat ' $n$ dinamiese geloofsverhouding verdring het. Murray toon onder andere aan dat dit die soewereiniteit van God beklemtoon het bo die Vaderskap van God. Die klem val op die wetsgedagte bo die Heilsboodskap; die determinisme van die uitverkiesing bo die verbondsverhouding. Die impak van hierdie hermeneutiese vakuum en die gepaardgaande gebrek aan 'n historiese bewussyn is sedertdien deur talle navorsers beklemtoon (sien veral Deist 1992; Loubser 1987).

Die onderliggende probleem is dus die reduksie van die Christelike geloof tot 'n a-historiese sisteem van geloofswaarhede en morele beginsels - wat kenmerkend is van die gereformeerde ortodoksie waarby die Oupajane aansluiting gevind het. Hierdeur is die dinamiese geloofsverhouding tussen God en mens gefikseer tot die kognitiese inhoud daarvan. Hierdie metodologie het weinig ruimte gelaat vir 'n self-kritiese evaluering van die beginsels waarmee só gewerk is.

\section{'N HISTORIESE EN HERMENEUTIESE BEWUSSYN}

Dit is opmerklik dat daar by die kritiese stem teen apartheidsteologie ' $n$ veel duideliker historiese (en hermeneutiese) bewussyn gevind kan word. Dit kan geïllustreer word aan die hand van die voorbeelde van Ben Marais en Beyers Naudé (Coetzee (2010: 371ev). Beide hierdie figure is diepgaande beïnvloed deur die Du Plessis-stryd en was toe reeds nie aangetrokke tot die teologiese werkswyse van die Oupajane nie. Beide is beïnvloed deur bepaalde ervaringe wat hulle ' $n$ aanvoeling gegee het vir die veranderende Suid-Afrikaanse konteks. Beide het daarom eerder gevra na die betekenis van die evangelie vir die bepaalde konteks. Dit hang waarskynlik saam met hulle persoonlike omstandighede en die wyse waarop hulle in Afrikanerkringe gemarginaliseer is. Hulle moes daarom intens worstel met die betekenis van die Christelike geloof vir hulle tyd. Hulle het teologiese nadenke daarom as 'n dinamiese en voortgaande proses verstaan. Veral Naudé het hoe langer hoe meer aansluiting gevind by ' $n$ vorm van profetiese teologie wat gemik is op die verstaan van die evangelie vir 'n spesifieke tyd in 'n spesifieke situasie (wat daarom ook 'n deeglike analise van die sosiale, ekonomiese en politieke veronderstel). Daar kan daarom by Marais en Naudé ' $n$ veel duideliker historiese bewussyn en ' $n$ hermeneutiese aanvoeling bespeur word - al het hulle dit nie noodwendig in 'n uitgewerkte teologiese metodologie of hermeneutiese teorie tot uitdrukking gebring nie.

'n Metodologiese verwerking van hierdie teologiese werkswyse het eers in die 1960s op gang gekom by ' $n$ volgende geslag teoloë vanuit die Ned Geref Kerk - waaronder veral die name van 
David Bosch (1929-1992), ${ }^{5}$ Jaap Durand (1935-), ${ }^{6}$ Willie Jonker (1928-2006) ${ }^{7}$ en Hennie Rossouw $(1933-)^{8}$ genoem kan word. Vanuit die Bybelwetenskappe het daar ook 'n steeds sterker hermeneutiese belangstelling na vore getree, maar dan eers ' $n$ dekade of later, byvoorbeeld in die bydraes van Ferdinand Deist, ${ }^{9}$ Bernard Lategan ${ }^{10}$ en Willem Vorster. Hierdie historiese en hermeneutiese bewussyn het ook gelei tot 'n nuwe belangstelling in hermeneutiek as vakrigting sodat talle publikasies oor Bybelse en teologiese hermeneutiek begin verskyn het. Hierdie nuwere belangstelling in hermeneutiek kan opsigself verstaan word as deel van die kritiese stem teen apartheidsteologie. Terselfdertyd kan die resultate van die hermeneutiese analises wat hieruit na vore gekom het benut word om die diepste punte van verdeling in die verband in meer besonderhede te beskryf.

Hierdie aanvanklike bydraes tot die hermeneutiek is opgevolg en verder gevoer deur verskeie ander teoloë sedert die 1980s. Dit is juis opvallend hoe ' $n$ belangstelling in hermeneutiek in

5 Sien veral Bosch 1972:129; 1981: 24ev; 1982; 1983:24ev en 1984:14ev)

6 Die ontluiking van 'n historiese bewussyn in kritiese afgrensing van die werkswyse van die gereformeerde ortodoksie blyk nêrens duideliker as by Jaap Durand nie. Hoewel Durand se formele hermeneutiese belangstelling eers later na vore getree het, is 'n steeds sterker aksent op die rol van die geskiedenis dwarsdeur sy loopbaan in sy teologiese nadenke te bespeur. In 'n Festschrift opgedra aan Durand sê Smit (2009:131-167) tereg: "Weinig ander Suid-Afrikaanse teoloë oor die afgelope dekades is deur so 'n radikale historiese bewussyn gekenmerk as Durand." Durand se worsteling om aan die ortodoksie te ontkom kom veral in sy tweede proefskrif na vore. In Heilsgeskiedenis en die dialektiek van syn en denke: Strukturele verbindingslyne tussen Thomas Aquinas en die teologie sedert die Aufklärung (1973). In die inleiding daarvan wys hy op 'n toenemende konsensus bestaan dat God se openbaring nie 'n "onthulling" is van 'n aantal "tydlose" waarhede nie, maar dat dit 'n openbaring is "wat in die geskiedenis ingegaan het". Hierdie openbaring moet volgens hom só vertolk word dat die aktualiteit daarvan vir die hede ontdek kan word (1973:1). Benewens sy dogmatiese werke, sien ook Durand se bundel Teks binne konteks (1986) en daarin veral die opstel "Die vinger van God in die geskiedenis: onopgeloste probleem".

7 In sy nadenke oor die verhouding tussen eksegese en dogmatiek beklemtoon Jonker eweneens die noodsaaklikheid van 'n hermeneutiese en historiese bewussyn in die interpretasie van die Skrif. Die betekenis van die Skrif kon vir Jonker nooit vir eens en vir altyd in dogmatiese waarhede gefikseer word nie, juis omdat geloof afgestem is op 'n dinamiese verhouding met God wat gevoed word deur 'n voortdurende omgang met die Skrif. Sien Jonker (1973:86-111, 1974, 1976).

8 Rossouw se doktorale tesis, Klaarheid en interpretasie: enkele probleemhistoriese gesigspunte in verband met die leer van die duidelikheid van die Heilige Skrif het in 1963 verskyn. In die inleiding stel hy dit duidelik dat hy hom in hierdie studie bepaal by die hermeneutiese probleem wat inderdaad dié vraagstuk van daardie tyd was. Hy beskryf hermeneutiek as die wetenskaplike leer van interpretasie "van verstanende en vertolkende uitleg" (1963:11). In hierdie werk toon hy aan dat die gebrek aan 'n historiese en hermeneutiese bewussyn by die gereformeerde ortodoksie 'n probleem skep vir die wyse waarop hulle die Skrif interpreteer - veral omdat dit die Christelike geloof laat verstar deur die inhoud daarvan in Aristoteliese begrippe te fikseer. In 'n essay "Doksologie, ortodoksie en ekumene" gee Rosouw (1973) opnuut aandag aan hierdie problematiek en wys spesifiek op die gebrek aan 'n historiese en hermeneutiese bewussyn binne die konteks van die gereformeerde ortodoksie.

9 Die ontluiking van 'n historiese bewussyn onder Bybelwetenskaplikes blyk by uitstek in Deist se Mosaïek van Moses (1976). Deist \& Burden se Die ABC van Bybelse eksegese tel onder die vroegste pogings om hermeneutiese insigte te sistematiseer. Hier moet ook melding gemaak word van sy monumentale ondersoek oor die Ned Geref Kerk se Skrifbenadering deur die geskiedenis heen (1994) - beginnende by die Skrifbeskouing van die eerste professore aan die Kweekskool op Stellenbosch (Hofmeijr en Murray).

10 Lategan het reeds in 1973 belangstelling in die hermeneutiek getoon toe hy die gereformeerdeskolastiese (metafisiese) beskouing van die Bybel bevraagteken het. Hy lewer 'n pleidooi dat die historiese karakter van die Skrif ernstig opgeneem word. Sien Lategan (1973:150ev). Verskeie ander werke wat op sy hermeneutiese bewussyn dui, het ook uit sy pen verskyn soos Lategan (1970a:22ev); Lategan (1970b:19ev) en Lategan \& Deist (eds) (1984:1ev). 
akademiese kringe in Suid-Afrika teen die 1970's en veral die 1980's ontwikkel het namate die kritiek teen apartheidsdenke in die Ned Geref Kerk toegeneem het. Hier kan veral melding gemaak word van die besondere bydrae van Dirkie Smit. Sy werk Hoe verstaan ons wat ons lees: 'n Dink- en werkboek oor die hermeneutiek vir predikers en studente (1987) het in die reeks Woord teen die lig verskyn, juis as 'n uitklaring van die werkswyse wat in die Christelike prediking gevolg word. ${ }^{11}$ Die Woord teen die lig-reeks as 'n geheel het trouens 'n belangrike aksent geplaas op die spanning tussen teks en konteks - wat in elke bydrae deur ' $n$ afdeling oor hermeneutiek oorbrug word.

Hierdie nuwe belangstelling in Bybelse, teologiese en kontekstuele hermeneutiek het gelei tot talle publikasies waarin die komplekse verskeidenheid van faktore wat die gebeure van interpretasie beïnvloed, ontleed en beskryf is. Hierdie analises bied ' $n$ nuttige instrument om die punte van verdeling tussen apartheidsteoloë en die kritiese stemme van Keet, Marais, Naudé en andere te identifiseer. In die res van hierdie bydrae maak ons veral gebruik van die latere analise van Conradie waarvolgens die volgende stel van sewe veranderlikes (Conradie (2008: 53ev) wat 'n rol speel in die vertolking van die evangelie vir die eietydse konteks geïdentifiseer word:

- Die historiese agtergrond van die teks;

- Die literêre kenmerke van die teks self;

- Die rol van kerklike en teologiese tradisies;

- Die handeling van interpretasie en die strategieë wat vir eietydse toepassing benut word;

- Die retoriese konteks waarbinne nuwe interpretasie plaasvind;

- Die eietydse konteks waarop nuwe interpretasies gemik word;

- Die verwringing van interpretasie deur onbewustelike faktore vanuit die sogenaamde wêreld-onder-die-teks.

Hierdie faktore word hier in 'n ander volgorde aan die orde gestel wat die punte van verdeling skerper uitlig.

\section{DIE ONTLUIKING VAN 'N HERMENEUTIEK VAN SUSPISIE}

Die verdeling tussen apartheidsteoloë en die kritiese stem in die Ned Geref Kerk daarteen blyk waarskynlik nêrens duideliker as in die af- of aanwesigheid van 'n hermeneutiek van suspisie nie. Die ontstaan en hoogbloei van apartheidsdenke in die Ned Geref Kerk kan juis verstaan word as 'n ideologiese legitimering van 'n bepaalde groep se ekonomiese, politieke en kulturele belange. Daarteenoor was daar vroeg reeds ' $n$ bepaalde agterdog aanwesig onder verteenwoordigers van die kritiese stem teen apartheidsteologie. Dit kan kortliks geïllustreer word aan die hand van die voorbeelde van Marais en Naudé (Coetzee 2010:382ev).

Dit is opvallend dat die eerste tekens van ' $n$ hermeneutiek van suspisie reeds vroeg by Marais bemerk kan word. As studenteleier het hy reeds die nasionalistiese denke van die Afrikaanse Nasionale Studentevereniging (met hulle wortels in nasionaal-sosialisme) bevraagteken en gekritiseer. Dit is versterk deur sy ervaring van die magspel wat na vore getree het in die Oupajane se stryd met Du Plessis. Dit was egter veral sy lees van Shillito se boek Nationalism: Man's other religion (1933) wat Marai se vermoede versterk het dat die ideologie van Afrikanernasionalisme 'n distorsie in die teologiese nadenke van die Oupajane veroorsaak het. Dit het sy oë geopen vir die rol wat rassisme speel in die teologiese legitimering van apartheid. Hierteenoor het hy homself eerder tuisgevind binne teologiese geledere waar eenheid in die kerk bevorder is ten spyte van rasseverskille en waar eenheid tussen volke bo rasse-apartheid in die burgerlike samelewing beklemtoon is. Dit was juis hierdie insigte wat sy oë geopen het vir die ideologie wat aanleiding gegee het tot distorsies in die denke van die apartheidsteoloë.

11 Sien ook Smit 1984:14ev; 1984:60ev; 1984:68ev en 2007. 
In talle artikels in kerklike tydskrifte in die 1940's stel hy ondersoek in na die wyse waarop en die rede waarom apartheidsteoloë teologiese en Skriftuurlike regverdiging kon vind vir die ideologie van rasse-apartheid. In 'n artikel in Op die Horison (Marais 1947:66) vra hy hoe dit moontlik is dat kleur belangriker is as broederskap in die kerk en medemenslikheid in die burgerlike samelewing. In sy doktorale tesis kom hy tot die gevolgtrekking dat Afrikaner nasionalisme aangewend word om goddelike sanksie aan die beleid van rasse-apartheid te verleen. In sy boek Die Kleur-krisis en die Weste lewer Marais (1952) vanuit 'n ander hoek kritiek op die ideologie van rassisme. Hy belig die rol wat die kleurfaktor in die meerderwaardigheid van Wes-Europeërs speel en wys daarop dat die argumente wat hierdie filosofie ondersteun, op mites berus. Hy toon aan dat die mite van bloed, ras en nadelige biologiese gevolge van rassevermenging reeds deur wetenskaplikes verwerp is. Hy bespreek dan die wyse waarop hierdie mites benut word in argumente wat rasse-apartheid regverdig. In hierdie boek maak Marais ook gebruik van bewyse uit die kerkgeskiedenis, die Bybel, en van resente internasionale kerkleiers en teoloë om apartheidsteoloë te waarsku teen die distorsies wat ideologieë veroorsaak in die teologie wat hulle bedryf.

In die geval van Naudé is daar sprake van 'n steeds toenemende bewuswording van ideologiese distorsies wat met apartheid en apartheidsteologie saamgehang het. Dit het al hoe skerper tot hom deurgedring dat Afrikaner nasionalisme 'n beslissende rol speel in die teologiese denke binne die Ned Geref Kerk en dat dit aanleiding gee tot kerklike strukture wat die eenheid van die kerk aftakel en 'n sosiale orde skep wat aanleiding gee tot ongeregtigheid, wat versoening onmoontlik maak. Hy het byvoorbeeld na die slagting by Sharpeville besef dat die leiers van die Ned Geref Kerk só verblind was deur hulle lojaliteit aan hierdie ideologie dat hulle bereid was om die besluite van die Cottesloe-beraad verdag te maak. Op grond van die werk van "Study Project on Christianity in an Apartheid Society (SPROCAS) het hy hoe langer hoe meer raakgesien dat die ideologie van Afrikaner nasionalisme nie net aanleiding tot sosiale en ekonomiese ongeregtigheid gee nie, maar dat daar aan onderliggend aan die rassestryd wat daardeur ontlok is, ook inderwaarheid 'n klassestryd in Suid-Afrika bespeur kan word.

\section{VERSKILLENDE ANALISES VAN DIE SAMELEWING}

In hermeneutiese teorieë word die rol wat analises van die eietydse konteks in teologiese interpretasie speel tipies beklemtoon. Rondom die weerstand teen apartheidsteologie het die aanwesigheid van 'n hermeneutiek van suspisie (al dan nie) saamgeval met radikaal verskillende analises van die uitdagings wat die Suid-Afrikaanse konteks aan kerk en teologie gestel het.

Apartheidsteoloë het in hulle analises gefokus op die sosio-ekonomiese en kultuur-politieke omstandighede van veral die armblankes en die bedreigings wat hulle ervaar het as gevolg van Britse imperialisme, die proses van verstedeliking en die getalleoorwig van die swart deel van die Suid-Afrikaanse bevolking. Uiteindelik het apartheidsteoloë al hierdie omstandighede gereduseer tot die sogenaamde armblankevraagstuk en die "naturellevraagstuk". Hoewel hulle analises self bevraagteken kan word, is daar klaarblyklik intensief aandag gegee aan ' $n$ sosiale analise van die konteks. Die Carnegie-verslag en Kerk en Stad bied goeie voorbeelde hiervan.

Die bydraes van Marais en Naudé word eweneens gekenmerk deur uitvoerige aandag aan sosiale analises, maar die resultate van die analise het al hoe meer ingrypend verskil van dié van apartheidsteoloë. Marais het veral op die aanwesigheid van rassespaning gefokus - soos blyk uit sy boeke Die Kleur-krisis en die Weste en The Two Faces of Africa (1964) (oor die einde van die koloniale tydperk) asook sy bespreking van die Tomlinson-verslag. Hy kom tot die gevolgtrekking dat die beleid van apartheid rassespanning en verdeeldheid sou laat eskaleer in die toekoms.

Naudé het die noodsaaklikheid van 'n deeglike sosiale analise besonder goed raakgesien. Dit 
blyk uit sy betrokkenheid by die Christelike Instituut en Pro Veritate, by die opstelling van The Message to the people of South Africa, die Programme to Combat Racism en veral by SPROCAS, wat juis gefokus het op ' $n$ analise van die sosio-ekonomiese omstandighede in Suid-Afrika in die vroeg-1970's.

Naudé het bekendheid verwerf vir sy vertroudheid met die dinamiek wat op gegewe tydstippe in die samelewing geheers het. Hy het nie net die politieke beleidsveranderinge skerp raakgesien nie. Hy het ook die dinamiek van die stryd teen apartheid van binne uit geken en pastoraal saamgeleef met die frustrasies, lyding en bitterheid wat daarmee saamgehang het. Sy analises het verskuif na gelang van veranderinge in die Suid-Afrikaanse konteks. Hy het toenemend meer vertroud geraak met die ongeregtighede in die samelewing en dit al hoe meer in terme van 'n klassestryd verstaan. Hy was ook intens bewus van die wyse waarop weerstand teen hierdie ongeregtighede onderdruk is deur ' $n$ uitgebreide netwerk van veiligheidsmagte. Hy het hierdie dinamiek verstaan in terme van die spiraal van geweld - van strukturele geweld, die gewelddadige reaksie daarop en die onderdrukking daarvan.

Hoewel die belang van ' $n$ indringende sosiale analise dus in al twee denkrigtings ingesien is, is die kern van die problematiek heel uiteenlopend verstaan. Dit bevestig dat hier sprake is van ' $n$ verdere punt van verdeling tussen die apartheidsteoloë en die kritiese stemme daarteen.

\section{DIE GEBRUIK VAN BYBELSE GEGEWENS}

Die lees en interpretasie van die Bybel bied nog ' $n$ invalshoek om die punte van verdeling tussen apartheidsteologie en die kritiese stemme daarteen te ondersoek. Dit hang saam met die wyse waarop 'n Bybelse regverdiging vir die beleid van apartheid in kerk en samelewing aangebied is. Daar word meermale gewys op die selektiewe benutting van Bybeltekste deur apartheidsteoloë (sien Botha AJ 1984:453ev; Lombard 1981:38ev); Loubser 1987). Die beginsel van skeiding word hiervolgens nêrens beter belig nie as in Genesis 11: 1-9, wat handel oor die Toring van Babel, waar die "Skeidingmaker" ingryp en die sonde van eenheid afweer. Dit word gesien as 'n model vir die verhouding tussen volke en nasies en selfs letterlik toegepas op die Groot Trek, wat hiervolgens 'n daad van gehoorsaamheid aan God se skeppingsordinansie was - wat verskeidenheid beklemtoon en skeiding voorgeskryf het. In Hand 2: 6, 8, 11 - wat handel oor die Pinkster-gebeure waar elkeen gehoor het hoe in hulle eie taal gepraat word - word 'n Nuwe-Testamentiese bevestiging van hierdie beginsel gevind. Daar word swaar gesteun op tekste soos Hand 17: 26 en Deuteronomium 32: 8, omdat dit die goddelike beginsel in verband met ' $n$ biologiese en geografiese gedifferensieerdheid bevestig.

Hierdie Skrifverstaan hoef nie hier verder bespreek te word nie, behalwe om weer te wys op die letterlike wyse waarop Bybelse gegewens toegepas is - en wat die gebrek aan van ' $n$ historiese of hermeneutiese bewussyn illustreer. Dit is juis hierdie punt waarop kritici soos Bennie Keet (1949) en Ben Marais (1948) gereageer het. Hulle wys daarop dat die letterlike toepassing van opdragte en die allegoriese uitleg van tekste onverantwoordbaar is.

In kort, wat die seleksie, verstaan en toepassing van tekste betref, is daar opvallende verskille tussen apartheidsteoloë en die kritiese stemme daarteen. Apartheidsteoloë het tekste gekies waarmee hulle die "beginsels" rondom skeiding (apartheid) kon regverdig. Hulle het die betrokke tekste gebruik om bepaalde ewig-geldende, universele en a-historiese goddelike beginsels te regverdig en het dit dan direk op die eietydse konteks toegepas. Alhoewel die kritici van apartheidsteologie nie noodwendig probeer wegkom het van die identifisering van geloofsbeginsels nie, het hulle tog op 'n ander wyse omgegaan met die Bybel. Vanuit ' $n$ intuïtiewe historiese en hermeneutiese bewussyn het hulle gepoog om die geselekteerde tekste te herinterpreteer in en vir hulle eietydse kontekste. 


\section{DIE ROL VAN TRADISIE EN DIE RETORIESE KONTEKS}

In hermeneutiese analises van veranderlikes wat 'n rol speel by teologiese interpretasie, word gewoonlik ook gewys op die sogenaamde "wêreld voor die teks", oftewel op die rol wat die tradisie van interpretasie speel. Die teologiese tradisie is van kardinale belang om die wortels van apartheidsteologie te verstaan - met spesifieke verwysing na die invloed van neo-Calvinisme, Princetonse fundamentalisme en Skotse piëtisme. Die Suid-Afrikaanse vorm van neo-Calvinisme kan verstaan word as ' $n$ bepaalde voortsetting van die gereformeerde ortodoksie en van ' $n$ vorm van Nederlandse neo-Calvinisme. Dit kan beskou word as 'n poging om hierdie tradisie binne die Suid-Afrikaanse konteks te vestig en te kontekstualiseer. Dit is egter nie noodwendig moontlik om op hierdie punt 'n duidelike verskil tussen apartheidsteologie en die kritiese stemme daarteen vanuit die Ned Geref Kerk self te identifiseer nie aangesien persone soos Keet, Marais en Naudé min of meer dieselfde teologiese wortels gehad het, al het hulle dalk ander aksente geplaas en sterker aansuiting gevind by die denkrigting binne die Ned Geref Kerk wat deur Du Plessis gesimboliseer word. Dit is juis hierdie gedeelde tradisie wat die problematiek wat hier aan die orde gestel word so interessant maak.

Hierbenewens kan ook gewys word op die rol wat die retoriese konteks speel in teologiese interpretasie (Conradie (2008: 101ev). Interpretasie vind naamlik nie in 'n lugleegte plaas nie - die vraag is aan wie teologiese diskoers gerig is en met watter beoogde impak. Dit is immers van deurslaggewende belang om te kan vasstel of ' $n$ bepaalde standpunt die heersende diskoers van die adressaat probeer bevestig, versterk, verder voer, uitdaag, konfronteer of verwerp. Hierdie meer spesifieke retoriese konteks kan dus onderskei word van die breër eietydse konteks waarbinne interpretasie plaasvind. Op hierdie punt kom 'n insiggewende punt van verdeling na vore: Indien 'n mens op grond hiervan vra na die teologiese gespreksgenote van apartheidsteologie, is dit besonder opvallend in watter mate hier van isolasie en selfs self-isolasie sprake was. Die bande met sekere groeperinge in gereformeerde denominasies in Nederland en die VSA is wel behou, maar van 'n kritiese interaksie met ander Europese of Amerikaanse strominge was daar nie veel sprake nie.

Meer nog, die wyse warop apartheidsteologie gefokus het op die kulturele selfhandhawing en politieke selfbeskikking van Afrikaners, het spoedig gelei tot vervreemding van ander gereformeerde kerke in die Suid-Afrikaanse konteks, van die breër ekumeniese beweging in Suid-Afrika en al hoe meer ook van die res van die familie van Ned Geref Kerke. Die kritiek wat vanuit ekumeniese geledere teenoor apartheidsteologie uitgespreek is, het hierdie tendens tot self-isolasie net versterk. Uiteindelik is apartheidsteologie gekenmerk deur afsondering en eksklusiwiteit en deur 'n laertrek-mentaliteit, die eiewillige geslotenheid wat so tipies van Afrikanernasionalisme was. Op hierdie wyse het apartheidsteoloë hulle afgesluit van die groter Christelike tradisie. Hulle kommunikasie was al hoe meer na binne gekeer, terwyl die gespreksgenote waarna hulle wel geluister het, al hoe meer geselekteer geraak het. As gevolg van die gebrek aan openheid vir kritiek van buite - en die demonisering van daardie kritiek - kon (wou) apartheidsteoloë nie raaksien in watter mate die evangelie misverstaan is en ook nie hoe kerklike praktyke aan ideologiese distorsie onderhewig was nie.

Tragies genoeg het presies hierdie self-isolasie hulle daarvan weerhou om die stemme van kritiek uit eie geledere in ag te neem. Hier was broeders wat binne hoorafstand gestaan het, maar die apartheidsteoloë wou hulle nie hoor óf verstaan nie. Hiermee is 'n stapsgewyse proses van selfisolasie voltooi - beginnende by modernistiese strominge in Europa, die wêreldwye ekumeniese beweging, ekumeniese stemme in Suid-Afrika, ander gereformeerde kerke in SuidAfrika, ander lede van die familie van Ned Geref Kerke en uiteindelik van die kritiese stem uit eie geledere. 
Hierteenoor is die ekumeniese blootstelling en kontak wat kritiese stemme soos Marais en Naudé gehad het besonder opvallend. Via hulle betrokkenheid by die ekumene is hulle blootgestel aan ander Christelike kerke in 'n internasionale en in die Suid-Afrikaanse konteks. In Marais se geval kan hier gewys word op sy ekumeniese studietoere en sy bywoning van die Tambaran-konferensie (1938). In Naudé se geval kan gewys word op sy bywoning van die Cottesloe-beraad en die Gereformeerde Ekumeniese Sinode in Potchefstroom (1950s), die vorming van die Christelike Instituut, sy betrokkenheid by onder andere die Message to the People of South Africa, die Programme to Combat Racism, sy rol as sekretaris-generaal van die SARK en uiteindelik sy voortgesette betrokkenheid saam met Wolfram Kistner via die Ecumenical Advice Bureau. In albei gevalle is hulle toenemend beïnvloed deur verskeie nuwe gespreksgenote namate hulle ekumeniese blootstelling toegeneem het.

Hierdie ekumeniese blootstelling het hulle gehelp om deur die oë van andere te kyk na die Suid-Afrikaanse konteks, na die Ned Geref Kerk, na die Bybel en na die eise van die evangelie en die Christelike geloof binne die Suid-Afrikaanse konteks. Meer nog, dit het by hulle'n sensitiwiteit aangewakker vir die wyse waarop die beleid van apartheid en die ideologieë van rassisme, klassisme en elitisme wat daarmee gepaard gegaan het, elke aspek van kerk en samelewing binnegesypel het. Dit is op grond van hierdie blootstelling en kontak met 'n wyer verskeidenheid van gespreksgenote dat hulle kritiek kon lewer ten opsigte van die Skriftuurlike regverdiging van apartheid (Marais), die wyse waarop apartheid as 'n kwasi-soteriologie en pseudo-evangelie gefunksioneer het (Bosch, Durand en Naudé) en die teologiese legitimering van 'n stelsel van politieke onderdrukking (Naudé).

Hierdie verskil in modus van teologiebeoefening karakteriseer dus by uitnemendheid die verdeling tussen apartheidsteologie en die kritiese stemme daarteen.

\section{INTERPRETASIE AS DIE INTEGRASIE VAN AL HIERDIE VERANDERLIKES}

Interpretasie behels per definisie toepassing en toeëiening, in hierdie geval die verstaan van implikasies van die Christelike geloof vir die Suid-Afrikaanse konteks. Hier is sprake van 'n spiraal van voortgaande interpretasie. Daar bestaan verskillende strategieë wat benut kan word in hierdie verband. Al hierdie strategieë behels die identifisering van bepaalde ooreenkomste te midde van die verskille wat andersins die verhouding tussen teks en konteks, oftewel die Christelike geloof en die samelewing vandag mag kenmerk. Gegewe die kompleksiteit wat hierdie verhouding kenmerk, word daar tipies van grondmetafore of teologiese modelle gebruik gemaak om 'n punt van vergelyking te vind op grond waarvan interpretasie in die eerste plek moontlik word. Hier kan ook gepraat word van heuristiese of dogmatiese sleutels met behulp waarvan interpretasie pas moontlik is (Conradie 2008: 80). Binne die Christelike tradisie is hierdie sleutels tipies van 'n soteriologiese aard. Hulle verwoord die wyse waarop hele kerklike en teologiese tradisies oor eeue heen die evangelie vertolk en die Christelike geloof verstaan en uitleef. Dit is juis hier waar die verskille tussen apartheidsteologie en die kritiese stemme daarteen die duidelikste blyk.

Apartheidsteoloë het van meer as een dogmatiese sleutel gebruik gemaak. Elke spesifieke sleutel het op 'n gegewe tyd ' $n$ meer dominante rol gespeel, maar nietemin later steeds ' $n$ invloed uitgeoefen. Die eerste sleutel wat 'n bepalende rol by Afrikaners in die koloniale tydperk gespeel het, is dié van selfbeskikking. Dit is na ongeveer 1930 toenemend vervang met die idee van "bevryding", waarna "skeiding" en "isolasie" groter voorhang geniet het.

"Roeping" en "selfbeskikking" was denkbeelde wat tydens die koloniale bewind aan die Kaap reeds ' $n$ belangrike rol gespeel het. Kultuur-godsdienstig het die Afrikaners hulleself verstaan in terme van die kultuur wat uit die corpus Christianum voortgevloei het. As direkte 
afstammelinge van die Wes-Europeërs en erfgename van hierdie kultuur het hulle hulself beskou as die draers van die "Christelike beskawing". Dit is juis hierdie kultuur wat aanleiding gegee het tot die oortuiging dat hulle die uitverkore volk van God is wat geroep is om as God se uitverkore werktuig aan die suidhoek van "donker Afrika" draers te wees van die "lig van die evangelie" na die "heidene". Die Afrikaners het dit toenemend beleef dat hierdie roeping wat hulle ontvang het, bedreig word, veral ná die vrystelling van die slawe aan die Kaap - wat benewens ander faktore, aanleiding gegee het tot die Groot Trek (vanaf 1834).

Dit was juis die Afrikaners wat deel van die Groot Trek was, wat ' $n$ intense vrees gehad het dat hulle hul meerderwaardige posisie teenoor die "heidene" sou moes prysgee en daarmee saam hulle roeping en reg tot selfbeskikking. Gedurende hierdie tydperk vind hulle'n Bybelse analogie in die wel en weë van Israel, wat as uitverkore volk van God deur God self beskerm word sodat hulle-hulle roeping kan vervul. God ken aan hulle die beloofde land (Israel) toe en verseker dat hulle veilig daar aanland en behoue bly te midde van die aanslae van die "heidene". Hierdie sleutel was ook bepalend vir die interpretasie wat die Afrikaner gemaak het tydens die Suid-Afrikaanse oorloë (1872-1884 en 1899-1902) - toe dit weer eens gegaan het oor hulle sogenaamde roeping en derhalwe selfbeskikking. Gedurende hierdie tydperk is die Britse imperialiste verstaan as die "farao" wat hulle bedreig, en die swart volke as die "heidense magte" teen wie hulle moet veg om selfbeskikking sodat hulle hul roeping kan vervul. Afrikaners het 'n ooreenkoms raakgesien met die posisie van Israel wat ook ter wille van hulle roeping getrek het na die "beloofde" land en hulleself daar gehandhaaf het.

Hierdie heuristiese sleutel van selfbeskikking is toenemend vervang met die idee van "bevryding". Dit gebeur veral ná 1902, toe die Afrikaners se omstandighede verander en hulle hulself in ' $n$ ander sosio-ekonomiese en kultuur-godsdienstige konteks bevind het. Die Afrikaner is oornag in 'n ekonomiese en maatskaplike krisis gedompel as gevolg van die Britse verskroeideaardebeleid, die wêreldwye depressie (1929), droogte (1930) en verstedeliking. Hulle was armlastig en het hulleself as die onderdruktes en gemarginaliseerdes beleef. Gedurende hierdie tydperk het die Ned Geref Kerk die kerk vir die Afrikanervolk geword, in só 'n mate dat beswaarlik onderskei kon word tussen kerk en volk.

Die eerste tekens van die Afrikaner se stryd om bevryding het gemanifesteer in die rebellie van die Afrikanermynwerkers onder aanvoering van genl. Christiaan de Wet. Hy het ook ander groepe Afrikaners, veral dié wat werkloos was, betrek by die stryd. Die Britse imperialiste en sogenaamde "swart massas" is geïdentifiseer as die magte waarvan die Afrikaner bevry moet word. Teen 1929 het die Ned Geref Kerk se leierskap hulle toenemend geskaar by die stryd van die onderdruktes en gemarginaliseerde Afrikaner. Hierdie stryd teen onderdrukking word dikwels verwoord, maar nêrens beter aan die orde gestel as in die Sendingbeleid van 1935 nie.

Apartheidsteoloë het nogmaals 'n Bybelse analogie gevind, naamlik dat God aan die kant van die verdrukte en gemarginaliseerde Israeliete was deur hulle van die farao in Egipte te verlos. Hierdie opvatting van die Afrikaners as die "onderdruktes" was nie beperk tot die eerste vier dekades van die 20ste eeu nie, maar het (minder sentraal) nog baie dekades in die geheue van die volk en kerk bly voortleef. Namate die verdrukkende magte gerelativeer is deur die verwerwing van politieke mag - en as gevolg daarvan ekonomiese bevoordeling - het die gebruik van hierdie sleutel vervaag.

Derdens het apartheidsdenkers gewerk met die dogmatiese sleutel van "skeiding". Dit was reeds onderliggend by die sinodesitting van 1857 toe die pragmatiese besluit geneem is in verband met afsonderlike dienste vir verskillende rassegroepe. Hierdie pragmatiese besluit van skeiding is tydens die sinode van 1880 vasgelê as ' $n$ beginsel wat gelei het tot die stigting van die Ned Geref Sendingkerk as afsonderlike denominasie. Die wortels van "skeiding" as ideologie kan reeds gesien word in die tydperk voor 1948, toe segregasie deur die Britse imperialiste 
ingevoer is. Die Afrikaner en die apartheidsteoloë in die Ned Geref Kerk het aansluiting gevind by hierdie beleid en het dit verder gevoer deur druk op die regering te plaas om wetgewing te aanvaar wat skeiding (tussen rasse) afdwing, veral ná 1948. Hierdie opvatting van "skeiding" is deur die apartheidsteoloë uitgewerk in verskeie dokumente waarin apartheid teologies begrond en Skriftuurlik geregverdig word. Die hele samelewing, dit wil sê op sosio-ekonomiese, kultuur-politieke en godsdienstige terreine, is op grond hiervan gestruktureer aan die hand van die motief van skeiding. Hierdie skeiding is deur apartheidsteoloë beskou as die enigste wyse waarop mense hulle eie identiteit gehandhaaf kon word. Dit was daarom die sleutel tot hulle redding.

Dit is wel opvallend hoedat apartheidsteoloë skeiding met voogdyskap verbind het om sodoende' $n$ morele basis daaraan te verleen. Voogdyskap was deel van hulle sogenaamde roeping wat hulle ontvang het en wat hulle verstaan het as opdrag van God om die "minderwaardige" rasse by te staan op elke terrein van hulle samelewing totdat hulle selfstandigheid bereik en as onafhanklike volk vir hulleself kon sorg.

'n Vierde kenmerkende sleutel by apartheidsteologie is die motief van "isolasie". Hierdie sleutel het vroeg reeds ' $n$ rol gespeel en word ook in die Sendingbeleid van 1935 op meer sistematiese wyse aangewend - nêrens word hierdie idee beter verwoord as in die bekende slagspreuk "in isolasie lê ons behoud en ons redding" nie. Die wyse waarop hierdie sleutel gefunksioneer het, word duidelik gedemonstreer in die gebeure tydens en na afloop van die Cottesloe-beraad, toe die meeste lidmate en leiers van die Ned Geref Kerk en die NP laer getrek en hulle selfs afgeskei het van die ekumene en die breër Christelike tradisie. Vir hierdie soort reaksie vind die apartheidsteoloë'n analogie in die Bybel waar Israel as uitverkore volk opgeroep word om hulleself af te skei van die ander volke - in die besonder deur gehoorsaam te wees aan die beginsels wat verbastering met ander volke verbied. Ook hierdie interpretasie word deurgevoer en toegepas deur middel van wette wat verseker dat die Afrikaner en lidmate van die Ned Geref Kerk geïsoleerd kan voortbestaan sodat hulle eie identiteit gehandhaaf kan word. Só het "skeiding" aanleiding gegee tot 'n laermentaliteit en totale isolasie.

Hierdie sleutels van skeiding, isolasie en selfbeskikking het ten diepste verband gehou met verskeie ander motiewe. Skeiding en isolasie was inderdaad konsepte wat ' $n$ bepalende rol gespeel het in die Afrikaner se ervaring van bedreiging en verswelging deur die "see van barbarisme". Daarom is afskeiding gesien as die enigste "redding" in hierdie omstandighede. Dit het immers hulle unieke identiteit en suiwerheid as Afrikaners verseker en hulle in staat gestel om "blanke beskaafde standaarde" in stand te hou. Voorts het dit hulle in staat gestel om hulle die sosiale meerderwaardigheid te handhaaf. Isolasie het op soortgelyke wyse redding gebied, want daardeur kon die Afrikaners op grond van groepskohesie oorleef en hulleself in die bedreigende omstandighede handhaaf. Hierdie denkbeelde het dus verband gehou met redding en oorlewing en kan daarom tereg as ' $n$ kwasi-soteriologie beskryf word (Coetzee en Conradie 2011).

Hierteenoor het die stemme van kritiek teen apartheidsteologie heel ander dogmatiese sleutels benut. Een voorbeeld hiervan is die motief van "gemeenskaplikheid" en in samehang daarmee die "broederskapsleer" wat 'n bepalende rol in Ben Marais se denke gespeel het. Marais argumenteer dat alle mense hulle waarde, posisie, doel en verwantskap daarin vind dat hulle aan God, hulle skepper, behoort. Elke mens is na die beeld van God geskape. Hulle vind hulle eenheid nie in die menslike natuur nie, maar deur Adam is daar ook 'n genetiese en genealogiese eenheid tussen alle mense. Vir hierdie idee vind hy 'n ooreenkoms in Paulus se uitsprake dat God uit een bloed al die nasies van die mensdom gemaak het om oor die hele aarde te woon (Hand 17: 26). Gemeenskaplikheid word dus deur die menswaardigheid van elke mens bepaal. Daarvoor vind hy 'n analogie in Matt 16: 26 waar die waarde van elke mens bó die 
van die hele materiële wêreld gestel word omdat alle mense voor God gelykwaardig is. Marais vind dus prototipes vir sy idee van gemeenskaplikheid in die Bybel. Dit oortuig hom dat alle mense, afgesien van hulle verskille meer in gemeen met mekaar het as dit wat hulle van mekaar skei.

Marais vind voorbeelde van hierdie "Christelike broederskapsleer" in die kerkgeskiedenis - in die besonder in die vroeë kerk en in die eietydse ekumeniese beweging waarby hy betrokke was. Hierdie broederskapsleer hang vir hom saam met die Vaderskap van God en die broederskap van Christus want "wie kinders van God is, is ook broers van mekaar". Hierdie broederskap word deur geen ander bande - of dit nou familie, ras, taal, bloed of nasionaliteit is - bepaal nie. Dit was juis op grond van hierdie sleutels dat hy indringende kritiek gelewer het op die apartheidsteoloë se idees van selfbehoud, skeiding en isolasie asook die Skriftuurlike regverdiging daarvan.

Die ironie was dat Marais se eie "broers" binne die Ned Geref Kerk sy verstaan van broederskap misken het. Vir die Engelssprekende kerke en die ekumeniese bewegings was Marais se denke egter ' $n$ teken van hoop omdat hy daarin geslaag het om deur sy interpretasie van die Christelike geloof 'n profetiese stem te laat hoor binne sy eie kerklike en sosiale konteks. Dit was juis op grond van hierdie sleutels dat Marais kon aantoon dat rasse-apartheid vir die Ned Geref Kerk méér geword het as net ' $n$ stelsel wat die Afrikaner se sosio-ekonomiese posisie verskans.

In Naudé se vroeëre lewensfase het "ongeregtigheid", veral vanweë "magsmisbruik", 'n beslissende invloed gehad op sy standpunte. Dat Naudé met die gebruik van hierdie motiewe die mees sensitiewe senuwee van die heersende kerklike en politieke magte aangeraak het, blyk uit die hewige reaksie wat dit ontlok het by die destydse magstrukture. As gevolg van Naudé se worsteling met ongeregtigheid en magsmisbruik het hy toenemend bewus geword van die rol wat rasse-apartheid gespeel het in die polarisering van bevolkingsgroepe binne die kerk en die burgerlike samelewing in Suid-Afrika. Dit ondermyn "versoening" in Christus omdat (rasse-) skeiding vir apartheidsdenkers van wesenlike belang is - rasse-apartheid het enige hoop op versoening tussen volke verydel.

Hierdie aksent kom reeds na vore in Naudé se intreerede as direkteur van die Christelike Instituut op 15 Desember 1963, toe hy 2 Korintiërs 5: 14-21 as teks gebruik het om die praktiese betekenis van versoening te beklemtoon. Hy toon aan dat versoening 'n unieke kenmerk is van die Christelike geloof en bespreek dan die praktiese implikasies wat dit inhou vir die kerk en die burgerlike samelewing. Versoening as dogmatiese sleutel het ook 'n bepalende rol gespeel in die pleidooi vir 'n "belydende kerk" in Suid-Afrika. Naudé wou hiermee nie net 'n bydrae lewer tot versoening binne die familie van Ned Geref Kerke nie - wat verskeurd was vanweë rasse-apartheid - maar ook tussen rasse binne die burgerlike samelewing. Versoening was die hooftema van die dokument Message to the people of South Africa, wat Naudé help opstel het. Hierdie dokument was die resultaat van 'n ekumeniese konferensie wat gehandel het oor die onderwerp van rassisme en apartheid as 'n pseudo-evangelie. Naudé het hierdie dokument aangewend om nie net versoening te verkondig nie maar om alternatiewe kerklike en samelewing strukture te ontwerp wat versoening bevorder (veral deur middel van SPROCAS).

Uiteindelik het Naudé ' $n$ finale teologiese verskuiwing ondergaan toe hy hom solidêr verklaar het met die onderdruktes en gemarginaliseerdes. Vervolgens sou hy die klem laat val op "bevryding". Hierdie beklemtoning word juis waargeneem in sy betrokkenheid by die swartbewussyn beweging en simpatie met swart en bevrydingsteologie. Hierdeur het hy gepoog om 'n bydrae te lewer tot die bevryding van die onderdrukte deel van die bevolking. Dit blyk ook uit sy standpunte rondom die moontlikheid van gewetensbesware en burgerlike ongehoorsaamheid. Hy het geweld verstaan as 'n uiterste maatreël wat ingespan moet word om die onderdruktes te bevry.

Die kontras tussen apartheidsdenke in die Ned Geref Kerk en die kritiese stem daarteen 
vanuit Ned Geref Kerkgeledere blyk nêrens sterker as hier nie. Dit is miskien juis hier waar die diepste punt van verdeling geïdentifiseer kan word. Terwyl apartheidsteoloë skeiding op grond van ras as noodsaaklik geag het vir die politieke, ekonomiese, sosiale en kulturele behoud van die belange van Afrikaners (vir hulle "redding"), het Naudé 'n totaal ander dogmatiese sleutel benut om die betekenis van die evangelie vir die Suid-Afrikaanse konteks te vertolk. Hiervolgens het redding eerder te make met die bevryding van verontregtes vanuit die sisteem wat ontwerp is om sulke Afrikanerbelange te handhaaf. Ten spyte van hierdie skerp kontras was Naudé nietemin van mening dat hy hiermee 'n sekere kontinuïteit gehandhaaf het met die hermeneutiese sleutel wat Afrikaners self benut het in hulle stryd teen Britse imperialisme. Hy het dit meer konsekwent deurgevoer deur sy analise van die identiteit van onderdruktes in 'n veranderende konteks.

\section{GEVOLGTREKKING}

Op grond van die bespreking hierbo kan die diepste punte van verdeling tussen apartheidsteoloë en die stemme van kritiek daarteen vanuit die Ned Geref Kerk self aan die hand van die volgende veranderlikes saamgevat word:

- Die aan- of afwesigheid van 'n historiese en hermeneutiese bewussyn;

- Die aan- of afwesigheid van 'n hermeneutiek van suspisie;

- Die verskille in die analise wat gemaak is van die eietydse samelewing;

- Die verskille ten opsigte van die gebruik van Bybelse gegewens;

- Die verskille ten opsigte van die ekumeniese konteks waarbinne teologiese retoriek gesitueer is (al dan nie);

Die verskille ten opsigte van die dogmatiese sleutels wat vir teologiese interpretasie benut is. Hierdie punte van verdeling het uiteindelik verreikende implikasies gehad - nie net binne teologiese debatte nie, maar ook vir amptelike kerklike diskoers. Dit kenteken verskille ten opsigte van 'n Christelike etos, praksis en spiritualiteit. Hierdie verskille het uiteraard tot en met 1994 veral na vore getree rondom die kerklike stryd teen apartheid. Dit het tot diepgaande verdeeldheid in kerklike kringe en veral binne die sogenaamde familie van Ned Geref kerke aanleiding gegee. Die Belhar belydenis kan verstaan word as die mees diepsinnige teologiese verwoording van hierdie verdeeldheid. In hierdie lig kry die stryd binne die Ned Geref Kerk rondom die aanvaarding van Belhar as 'n belydenisskrif nuwe betekenis. Dit is nietemin duidelik dat die dogmatiese sleutels wat in apartheidsteologie benut is nie meer dominant is in die Ned Geref Kerk nie. Hoe kan dit ons help om die diepste punte van verdeling in teologiese diskoers in ons eietydse konteks te verstaan? In 'n opvolg bydrae hoop ons om hierdie vraagstuk verder te ondersoek.

\section{BIBLIOGRAFIE}

Adonis, JC 1982. Die afgebreekte skeidsmuur weer opgebou. Amsterdam: Rodopi.

Bax, D 1975. "Hammanskraal ... A vital Christian witness to fundamental change." Pro Veritate, 15 April, 13: $12,12-15$.

Bax, D 1979. A different gospel: A critique of the theology behind apartheid. Johannesburg: Presbyterian Church of South Africa.

Boesak, A 1973. "Is apartheid kerke se skuld". Pro Veritate, Februarie, 11: 10, 5-7, 21.

Boesak, A 1977. Farewell to Innocence. A social-ethic study of black theology and black power. Johannesburg: Ravan Press.

Boesak, A 1983. “He made us all, but.....," In De Gruchy, JW \& Villa- Vicencio, C: Apartheid is a heresy, 1-9. Cape Town: David Philip.

Boesak, A 1984. Black and Reformed: Apartheid, liberation and the Calvinist tradition. Johannesburg: Skotaville. 
Boesak, A 1986. "If this is treason, I am guilty". In Tlhagale, B \& Mosala, I: Hammering swords into ploughshares. Essays in honour of Archbishop Mpilo Desmond Tutu, 279-300. Johannesburg: Skotaville. Boesak, A 1987. If this is treason I am guilty. Grand Rapids, Mich: Wm B Eerdmans.

Bosch, DJ 1972. "Geestelike opbou en ekumeniese betrekkinge by die Ned Geref Dogterkerke". Nederduitse Gereformeerde Teologiese Tydskrif, Junie, 13: 3, 129-149.

Bosch, DJ 1981. "Kerk en politiek in die Suid-Afrikaanse konteks". In Smith, NJ, O’Brien Geldenhuys, FE \& Meiring, PGJ (reds): Storm-kompas. Opstelle op soek na 'n suiwer koers in die Suid-Afrikaanse konteks van die jare tagtig, 24-37. Kaapstad: Tafelberg.

Bosch, DJ 1982a. "Nothing but a heresy". In De Gruchy, J \& Villa-Vicencio, C (eds): Apartheid is a heresy. Grand Rapids: Eerdmans.

Bosch, DJ 1982b. "In gesprek met dr. PF Theron". In Bosch, DJ (et al.) 1982. Perspektief op die ope brief 134142. Kaapstad: Human en Rousseau.

Bosch, DJ 1983. "Nothing but a heresy". In De Gruchy, JW \& Villa-Vicencio, C (eds): Apartheid is a heresy, 24-38. Cape Town: David Philip.

Bosch, DJ 1984. "The roots and fruits of Afrikaner civil religion". In Hofmeyr, JW \& Vorster, WS (eds): New Faces of Africa: Essays in honour of Ben (Barend Jacobus) Marais, 14-35. Univercity of South Africa: Pretoria.

Bosch, DJ 1982c. "The Church as alternative community". Studiestuk no 170. Instituut vir Reformatoriese Studies. Wetenskaplike bydraes van die PU vir $\mathrm{CHO}$.

Bosch, DJ 1985. "The fragmentation of Afrikanerdom and the Afrikaner Churches". In Villa-Vicencio, C, De Gruchy, JW (eds): Resistance and hope. South African essays in honour of Beyers Naudé, 61-73. Cape Town: David Philip.

Botha, AJ 1984. Evolusie van 'n volksteologie: 'n Historiese en dogmatiese ondersoek na die samehang van kerk en Afrikanervolk in die teologie van die NG Kerk, met besondere verwysing na die apartheidsdenke wat daaruit ontwikkel het. Ongepubliseerde D.Th-proefskrif, Universiteit van Wes-Kaapland.

Cloete, GD \& Smit, DJ (reds) 1984. 'n Oomblik van waarheid. Opstelle rondom die NG Sendingkerk se afkondiging van 'n status confessionis en die opstel van 'n konsepbelydenis. Kaapstad: Tafelberg.

Coetzee, MH 2010. Die "Kritiese stem" teen apartheidsteologie in die Ned Geref Kerk (1905-1974): 'n Analise van die bydraes van Ben Marais en Beyers Naudé. Ph.D- proefskrif, Universiteit van Wes-Kaapland.

Coetzee, MH \& Conradie, EM 2011. Apartheid as quasi-soteriology: The remaining lure and threat. Journal of Theology for Southern Africa (forthcoming).

Conradie, EM 2008. Angling for interpretation. A first introduction to biblical, theological and contextual hermeneutics. Stellenbosch: Sun Press.

Deist, FE 1986. Kan ons die Bybel nog glo? Pretoria: Van Schaik.

Deist, FE 1994. Ervaring, rede en metode in skrifuitleg. 'n Wetenskapshistoriese ondersoek na Skrifuitleg in die Ned Geref Kerk, 1840-1990. Pretoria: RGN.

De Klerk, WA 1975. The Puritans in Africa: a story of Africanerdom. London: Rex Collings.

Durand, JJF 1973. Heilsgeskiedenis en die dialektiek van syn en denke: strukturele verbindingslyne tussen Thomas Aquinaas en die theologie sedert die Aufdklärung. Ongepubliseerde doktorale proefskrif. Universiteit van Stellenbosch.

Durand, JJF 1978. "Bible and race: The problem of hermeneutics". Journal of Theology for Southern Africa, September, 24: 3-11.

Durand, JJF 1980. "Die vinger van God in die geskiedenis - 'n Onopgeloste probleem". In Teks binne konteks: Versamelde opstelle oor kerk en politiek, in die reeks Teks en konteks, 91-99. Bellvile: Universiteit van Wes-Kaapland.

Durand, JJF 1984a. "'n Belydenis - was dit werklik nodig?". In Cloete, GD \& Smit, DJ (reds): 'n Oomblik van waarheid, 39-48. Kaapstad: Tafelberg.

Durand, JJF 1984b. "Belhar- krissispunt vir die NG Kerke”. In Cloete, GD \& Smit, DJ (reds): 'n Oomblik van waarheid, 123-134. Kaapstad: Tafelberg.

Engdahl, HSA 2006. Theology in conflict - readings in Afrikaner theology: The theologies of FJM Potgieter and $B J$ Marais. Frankfurt am Main: Peter Lang.

Heaney, MJ 2004. Beyers Naudé, ekumeniese baanbreker in Suid-Afrika: 1960-1994. Ongepubliseerde doktorale proefskrif. Fakulteit Teologie, Universiteit van Pretoria.

Hexham, I 1981. The irony of apartheid: the struggle for national independence of Afrikaner Calvinism 
against British imperialism. New York: The Edwin Miller Press.

Jonker, WD 1973. "Dogmatiek en Heilige Skrif”. In Bakker, JT, Hartvelt, GP, Kuitert, HM en Meuleman, GE

(reds): Septuagesimo anno - theologische opstelle aangeboden aan Prof. Dr. GC Berkouwer, 86-111.

Kampen: JH Kok.

Jonker, WD 1976. Woord as opdrag: gedagtes oor die prediking. Pretoria: NG Kerkboekhandel.

Kinghorn, J (red) 1986. Die NG Kerk en apartheid. Johannesburg: Mac Millan.

Keet, BB 1949a. "Die Heilige Skrif en apartheid I". Die Kerkbode, 30 November, 64: 22, 1004-1005.

Lategan, BC 1970a. "Voorlopers van die Hermeneutiek". Nederduitse Gereformeerde Teologiese Tydskrif, Januarie, 11: 1, 22-28.

Lategan, BC 1970b. “Hermeneutiek en geskiedenis”. Neotestamentica, 4: 35, 19-38.

Lategan, BC 1973. "Vereistes vir effektiewe NT hermeneutiek". Nederduitse Gereformeerde Teologiese Tydskrif, Januarie, 14: 2, 150-155.

Lategan, BC 1984. "Current issues in the hermeneutical debate". Neotestamentica, 18, 1-17.

Lombard, RTJ 1974. Die Nederduitse Gereformeerde Kerk en rassepolitiek. Met spesifieke verwysing na die jare 1948-1961. Pretoria: NG Kerkboekhandel.

Lombard, RTJ 1981. Die Nederduitse Gereformeerde Kerk en rassepolitiek met verwysing na die jare 19481961. Silverton: Promedia-Publikasies.

Loubser, JA 1987. The apartheid bible. A critical review of racial theology in South Africa. Kaaspstad: Maskew Miller Longman.

Marais, BJ 1946. Die Christelike Broederskapsleer en sy Toepassing in die Kerk van die Eerste Drie Eeue. Ongepubliseerde D.Phil-proefskrif. Universiteit van Stellenbosch.

Marais, BJ 1948. "Die Skrif en rasse-apartheid". Die Kerkbode, 14 Julie, 62: 2, 1596-1597.

Marais, BJ 1950. "Die Skrif en rasse-apartheid". Die Gereformeerde Vaandel, Februarie, 18: 1, 14-25.

Marais, BJ 1952. Die Kleur-krisis en die Weste: 'n studie insake kleur en kleurverhoudings in die Amerikas. Johannesburg: Goeie Hoop Uitgewers.

Marais, BJ 1964. The Two Faces of Africa. Pietermaritzburg: Shuter \& Shooter.

Maritz, PJM 2003. Ben Marais (1909-1999): The influences on, and heritage of a South African prophet during two periods of transformation. Ongepubliseerde Doktorale proefskrif. Universiteit van Pretoria.

Murray, AH 1935. "Calvinisme volgens opvatting van die Afrikaner se kerk". In "Bekommerd": Christus die deur die twee rigtings van Calvinisme, 61-67. Kaapstad: Haum.

Mofokeng, T 1986. "The evolution of the black struggle and the role of black theology". In Mosala, IJ \& Tlagale, B (eds): The unquestionable right to be free. Essays in Black Theology, 113-128. Johannesburg: Skotaville.

Naudé, CFM 1962. "Wat ons wil”. Pro Veritate, 15 Mei, 1: 1, 3.

Naudé, CFM 1963. "Die taak van die profeet". Pro Veritate, 15 November, 2: 7, 3.

Naudé, CFB 1995. My land van hoop. Die lewe van Beyers Naudé. Kaapstad: Human \& Rousseau.

Nolan, A 1986. "Theology in a prophetic mode". In Tlhagale, B en Mosala, I (eds): Hammering swords into ploughshares. Essays in hounor of Archbishop Mpilo Desmond Tutu, 131-140. Johannesburg: Blackshaws.

Nolan, A 1988. God in South Africa: The challenge of the gospel. Cape Town: David Philip.

Pauw, JC 2008. Anti-apartheid theology in the Dutch Reformed Family of Churches. A depth-hermeneutical analysis. Ongepubliseerde doktorale proefskrif Amsterdam: VU.

Ras, Volk en Nasie en Volkereverhoudinge in die Lig van die Skrif. Goedgekeur en aanvaar deur die Algemene Sinode van die Ned Geref Kerk, Oktober 1974. Kaapstad: NG Kerk-Uitgewers.

Rossouw, HW 1963. Klaarheid en interpretasie: enkele probleemhistoriese gesigspunte in verband met die leer van die duidelikheid van die Heilige Skrif. Doktorale proefskrif. Amsterdam: Jacob van Campen.

Rossouw, HW 1973. “Doksologie, ortodoksie, eukumene”. In Bakker, JT, Hartveld, JP, Kuitert, HM en Meuleman, GE (eds): Septuagesimo anno theologische opstelle aangeboden aan Prof. Dr. GC Berkouwer, 203-212. Kampen: JH Kok.

Ryan, C 2005. Beyers Naudé. Pilgrimage of faith. Cape Town: David Philip.

Shillito, E 1933. Nationalism: Man's other religion. Chicago: Willet Clark \& Company.

Smit, DJ 1987. Hoe verstaan ons wat ons lees? 'n Dink- en werkboek oor die hermeneutiek vir predikers en studente. Woord teen die lig B/1. Kaapstad: NG Kerk-Uitgewers.

Smit, DJ 2009a. "In die geskiedenis ingegaan". In Conradie, E \& Lombard, C (eds): Discerning God's justice in 
church, society and the academy. Festschrift for Jaap Durand, 131-167. Stellenbosch: Sun Press. Stoker, HG 1941. Die stryd om die ordes. Pretoria: Caxton.

Villa-Vicencio, C 1988. Trapped in apartheid. A socio-theological history of the English-speaking churches. Cape Town: David Philip.

Villa-Vicencio, C \& de Gruchy, JW (eds) 1985. Resistance and hope. South African essays in honour of Beyers Naudé. Grand Rapids: Wm B Eerdmans.

Walshe, Peter 1982. The rise of African nationalism in South Africa. The African National Congress 19121952. Los Angeles: Univercity of California Press.

Walshe, Peter 1997. "'Christianity and the anti-apartheid struggle': The prophetic voice within divided churches". In Elphick, R \& Davenport, R (eds): Christianity in South Africa a political, and cultural history, 383-399. Los Angeles: Univercity of California Press.

\section{KEY WORDS}

Apartheid theology

Critical voices

Hermeneutics

Ben Marais

Beyers Naudé

\section{TREFWOORDE}

Apartheidsteologie

Kritiese stem

Hermeneutiek

Ben Marais

Beyers Naudé 